\title{
Becoming more Like Friends
}

\author{
A Qualitative Study of Personal Media and Social Life
}

\author{
MARIKA LÜDERS
}

\begin{abstract}
Mediated interaction plays a significant role in the social life of adolescents in Norway. The purpose of the present article is to examine the qualities of mediated interaction and the integration of mediated and immediate social spheres, suggesting that the ability to juggle between online and offline social spheres has become a characteristic element of social competence in network societies. More specifically, the analysis looks at the use of personal media for maintaining and developing existing social relationships and for extending social networks. Qualitative interviews with 20 Norwegian adolescents constitute the empirical base. The analysis explains how interaction takes on mundane forms, confirming the value of social relationships between in-person meetings. Moreover, it is argued that mediated communication differs from face-to-face communication, not by being less meaningful, but by enabling other forms of disclosing practices. Mediated forms of communication, hence, have an influence on the character of social ties and networks.
\end{abstract}

Keywords: youth, social networks, personal media, network society, communication

\section{Introduction}

Countless accounts of digital connections, relationships and networks have been offered during recent years, emphasizing the mundane quality yet increasing importance of social technologies in everyday life (e.g., Boase et al., 2006; Donath and Boyd, 2004; Heim et al., 2007; Herring, 2004; Livingstone and Bober, 2005; McKenna et al., 2002; Torgersen, 2004; Wellman and Haythornthwaite, 2002). There is consequently reason to assume that personal media, defined as tools for interpersonal communication, play a significant social role in modern societies. The current article presents a qualitative analysis of how 20 adolescent users in Norway experience mediated forms of interaction as highly meaningful, and how their performances have offline social implications. It is tentatively argued that it is important to have the skills to live and practice in mediated as well as immediate arenas, employing different forms of personal media for different purposes, contacts and time of day. Considering the high numbers of adolescent users with access to personal media such as mobile phones, instant messenger (IM) and social network sites, the present study aims to explain why mediated spaces of interaction have become so significant for individual users. What is the attraction?

I first briefly address social interaction in a modern societal context. Thereafter, I introduce a more specific research question, before depicting the methodological procedures used here. The main part of the article concerns mediated social practices: 
first, by analysing use of personal media for maintaining and developing close social relationships, and second, by analysing how use of personal media may extend social networks. A number of similar studies have been conducted and constitute a crucial context for the analysis. Thus, discussions of relevant literature and prior research are presented in parallel to the empirical analysis of the qualitative interviews conducted for the present study. In the final part of the article, the main findings are summarized and implications for future research are suggested.

\section{Background: Face-to-face and Mediated Interaction in Network Societies}

The approach of symbolic interactionism emphasizes the personal importance of human interaction, based on the use of symbols and their shared meaning (Blumer, [1969] 1998; McCall, 2003: 328). Similarly, perceptions of self are partly moulded by interpreting the responses and reactions of other people. As identified by sociologist Graham Allan, "[n]ot only do our friends help to provide us with our sense of identity, but they also confirm our social worth" (Allan, 1989: 1). Allan emphasizes the significance of a frequent level of face-to-face contact between friends in order to keep relationships active and alive (Allan, 1989). He furthermore maintains that letters and telephone calls may be important in these processes, but that, for most friendships, regular face-to-face meetings are essential. Similarly, Peter L. Berger and Thomas Luckmann stress the importance of being emphatically close through a maximum of expressions: "[the] most important experience of others takes place in the face-to-face situation, which is the prototypical case of social interaction. All other cases are derivates of it" (Berger and Luckmann, 1967: 28). However, with the present abundance of communication media, mediated interaction has become increasingly important. As Caroline Haythwornthwaite argues, face-to-face may be the extension of online communication rather than vice versa (Haythornthwaite, 2002: 388). Young people do not necessarily accept that face-to-face communication is superior in all situations, and communication technologies are used pragmatically as valuable supplements to immediate interaction (Lenhart et al., 2005; Livingstone and Bober, 2004; Oksman and Turtiainen, 2004): “... rather than seeing face to face communication as automatically superior, as do many adults, young people instead evaluate the different forms of communication available to them according to distinct communicative needs" (Livingstone and Bober, 2005: 16).

Whereas personal media are mundane and part of everyday life, the increasing importance of mediated social arenas contributes to making social life more complex. Interestingly then, personal media are part of what increases complexity in modern societies and are simultaneously tools used to handle this complexity. Furthermore, a conceptual focus on "network societies" suggests that life is not merely concerned with local neighbourhoods, epitomized in the form of Ferdinand Tönnies's gemeinschaft, which is ideal-typically described as a uniform and static village, characterized by intimate and enduring interpersonal relationships. On the other end of Tönnies's continuum of social systems, gesellschafts represents typical industrial city societies, characterized by relationships selected and used for achieving specific ends (Tönnies and Loomis, 1955). In network-theoretical terms, societies are instead depicted as being made up of dynamic networks of connected nodes, characterized by relations of different types (Barabási, 2003; Granovetter, 1973). Studies of social networks have been conducted for several decades, demonstrating that individuals are part of multiple, heterogeneous and sparsely-knit structural systems (Wellman, 2001), hence the term "network society". 
Individuals concomitantly switch between ties and networks to serve purposes of socialization and collaboration and to achieve a sense of belonging (Wellman, 2002). Whereas this initially appears to be similar to Tönnies's gesellschaft, it is suggested that the notion of network societies emphasizes relations of more various types: The individual is the centre of her or his social life, which is characterized by intimate as well as instrumental ties (see also Rasmussen, 2007).

Often, and perhaps most significantly, social ties are still maintained through faceto-face meetings, yet in many cases, mediated forms of communication emerge as appropriate tools and are able to facilitate highly meaningful practices. In order to understand these processes, it is therefore necessary to consider the interdependent and yet sometimes independent relationships between online and offline forms of communication. It is initially proposed that a well-developed social competence, defined as the ability to function effectively in social contexts (Cavell, 1990) or skilled social behaviour (Heim et al., 2007), entails the proficiency to utilize mediated forms of interaction as well as face-to-face communication. The present article consequently aims to answer the following research question: Given that mediated forms of interaction are socially important, how can these be meaningfully applied and integrated into the social lives of individual users? The analysis accordingly also considers in what ways mediated forms of interaction are important.

\section{Method}

Surveys and quantitative studies confirm the pervasiveness of mobile phones and computer-mediated forms of interaction among adolescents in countries such as the UK, the US and Norway (Lenhart et al., 2005: Livingstone, 2005 \#82; Statistics Norway, 2005; Torgersen, 2004). But quantitative surveys are not as useful in analysing the details and nuances of mediated interaction and the ensuing social implications. Therefore a qualitative approach is more appropriate in addressing the present research question. Consequently, the aim is not to statistically generalize the results to Norwegian youth, but to augment comprehensions of the dynamics and characteristics of mediated interaction through analytical generalizations (see also Yin, 1994: 10).

\section{Data Collection and Analysis}

Thirty-two potential informants were contacted based on their online presence in the form of blogs/online diaries or social networking services such as MySpace. Initial contact was made by e-mail, by message-services in social applications such as MySpace or by IM, with information about the research project and an invitation to take part in the study. Twelve girls and eight boys between 15 and 19 years of age agreed to participate and were interviewed between 2004 and 2006. Fifteen informants were from Oslo or from urban and rural areas within 200 kilometres of Oslo. Five interviews were conducted using MSN Messenger ${ }^{1}$. These interviews provided explicit information about the character of interactions in mediated arenas, and the form of these interviews is thus very relevant to the research question posed. The Messenger interviews were conducted with informants in other parts of the country ${ }^{2}$.

Face-to-face interviews were conducted where the informants preferred, usually at a café. The informants were promised anonymity and fictional names appear in the article. Two of the interviews were with groups of four and three girls. These girls were 
among the youngest informants and preferred to be interviewed together with friends. Interview protocols were developed to suit the specific informant, but were in all cases based on the same format, with questions about interplay patterns and use of personal media, as well as more specific questions about the personal and social importance of mediated interaction and online expressions. The interviews lasted between 70 and 130 minutes.

The interviews were audio-recorded and transcribed. They were then coded and analysed using TAMS Analyzer, an open-source application for qualitative data analysis ${ }^{3}$. As the study is based on qualitative interviews with a limited number of users, all of whom are relatively heavy users of social technologies, I have had the opportunity to explore how highly experienced users perceive the value of mediated forms of interaction. Complex interplay patterns of personal media appear in this study, as the informants use an array of tools such as online diaries/blogs, photo/art-sharing services, IRC and, in certain cases, even "old-fashioned" letters in addition to statistically more common communication devices such as the mobile phone, social profiles/networking sites (e.g. MSN profiles/Window Live Spaces, MySpace and blink.no) ${ }^{4}$, e-mail and IM. The rich experiences of the informants are essential for developing theories of contextualized mediated interaction. There is, moreover, a noticeable benefit of interviewing people with online diaries, blogs or other forms of online presences, where users choose to present themselves and aspects of their lives in specific ways. These impressions of the interviewees have been important prior to and during the interviews, as well as in the analysis of the interviews. The present aim is to increase our knowledge about individual social practices, and the experiences of the informants are employed to develop analytical generalizations about the significance that mediated communication may have. Even if connections between the mediated and immediate spheres of life are strongly emphasized, the present article also focuses on the particularities of mediated forms of interaction. Finally, the socio-economical backgrounds of the informants differ substantially, yet they all have regular access to networked computers, and the analysis does not discuss potential differences between the informants based on their socio-economical backgrounds.

The remaining part of the article is divided into two parts. The first part focuses upon the use of personal media in order to maintain existing social relationships, and the second part explores how mediated interaction initiates new relationships and hence extends social networks.

\section{Maintaining Close Social Relationships through Mediated Interaction}

Sonia Livingstone and Magdalena Bober show that communication technologies such as mobile phones, IM and e-mail are important means for sustaining social networks and strengthening already existing friendships among British adolescents (Livingstone and Bober, 2004; Livingstone and Bober, 2005). Other quantitative studies confirm that the amount of IM use is positively associated with affective and social intimacy, and that IM use encourages face-to-face meetings (Hu et al., 2004). A survey about user patterns in online communities shows that $30 \%$ of the general Internet population in Norway (representative in terms of geographical location, gender and age) visits a community (Norwegian or international) daily or several times a week (Brandtzæg and Heim, 2007), though the percentage among younger users is probably significantly higher. Face-to-face communication remains the preferred mode of interaction (Baym and Zhang, 2004), but 
mediated communication increases social arenas in time and space. In a large quantitative study of Norwegian youths, the analysis shows a significant decrease in feelings of loneliness between 1992 and 2002. Kristinn Hegna suggests that mobile phones and social technologies partly explain this development (Hegna, 2005: 43). All of these studies indicate that mediated forms of communication are socially important. However, there is a need to explore how young people employ mediated forms of communication to create meaningful social practices. The following analysis explains how personal media increase the temporal and spatial flexibility of everyday life: The interviewees use mediated forms of communication primarily to sustain meaningful relationships between face-to-face meetings. It is further argued that the specific qualities of mediated communication are valuable for strengthening social relationships. I finally explain how social technologies make different characteristics of ties more explicit.

For young people, everyday life consists of compulsory school activities, family life, social life and practices related to interests and sports. Everyday schedules can be busy: After school, from about two to four or five p.m., Stine (15, Oslo) connects to MSN Messenger (now Windows Live Messenger), occasionally writes in her LiveJournal, reads updates from her friends' LiveJournals, and primarily does her homework. From four or five p.m. she practices ballet. To Stine, the computer is a practical tool for effectively keeping in touch with friends when she does not have time or occasion to meet them face-to-face, and similarly important as a tool for planning offline social meetings when she has time off. Her social life is largely shaped by how she manages to integrate online and offline social practices, enabling her to navigate between school, homework, ballet and friends. She is annoyed by her mum, who thinks it is asocial to spend time in front of the computer: "She thinks it's nerdy to chat on MSN instead of going out to meet somebody for 30 minutes before you have to go back home." Stine's mother expresses mundane concerns that are reflected among scholars who consider that mediated communication represses the significance of face-to-face interactions and represents communication of a lesser quality (e.g., Barney, 2004; Fortunati, 2005; Gergen, 2002). Mark Poster asserts that the judgement of the computer as asocial is "characteristic of the moralism with which the introduction of information technologies is greeted" (Poster, 2001: 109). Poster's point is that the alleged loss of community caused by technologies is a process that began with the book and the liberation of the mind from the co-presence of other bodies. Similarly, personal media facilitate possibilities for social interaction liberated from physical presence. Stine's matter-of-fact appropriation of mediated communication signifies a desire to be social. Accusations of being asocial therefore seem overtly paradoxical.

Use of personal media is similarly primarily socially motivated among all of the informants and personal media are employed to extend social arenas, also among those who are socially outgoing in the first place. Kristoffer $(18$, Oslo) is, in social network terms, something of a social hub and very easily befriends people: at school, clubs, work assignments, concerts, parties or wherever his actions take him. He explains how personal media are important tools for keeping friendships alive between offline meetings, for example, in the form of sms conversations with people before he goes to bed. Any time and any place represent possible moments of social encounters (Oksman and Turtiainen, 2004), as technologies of communication are used to construct a connected presence when people are physically distant (Licoppe and Smoreda, 2005: 321). To other users, mediated social practices are quite essential, simply because distance makes face-to-face meetings rare. Dina (15, Oslo) always keeps her cell phone in close proximity in order to 
text friends throughout the day. Moreover, there is a special someone for whom she needs to be available: "I panic if I don't have my mobile phone with me. What if Rikard tries to call me!" Personal media are indispensable for their romantic relationship by decreasing the barrier of a geographical distance of 1100 kilometres that separates them. Similarly, Camilla (17, Oslo) experienced how, when a friend moved to England, they revitalized their relationship through frequent e-mailing. Reconstituting idle social relationships is an important part of the attraction of mediated communication, especially as mobility arguably is a characteristic part of modern life. This can be seen, for instance, with young people who regard travelling as a "compulsory" life-shaping experience. Deciding to be an exchange student is easier and more manageable with the prevalence of social technologies. "Where a person lives ... is a matter of choice organised primarily in terms of the person's life-planning" (Giddens, 1991: 147). The commonness of personal media can correspondingly be said to support a modern quasi-nomadic lifestyle.

Because of the specific qualities of mediated communication, offline friendships may evolve further through online communication, regardless of whether distance is an issue. According to Marte (15, Trondheim), IM makes it easier to keep in touch with friends as "some people are more open online", initially indicating that mediated forms of communication are important for users who consider themselves to be shy in faceto-face settings. However, extrovert informants too find mediated meetings appealing for these reasons. In the key article "Computer-Mediated Communication: Impersonal, Interpersonal and Hyperpersonal Interaction", Joseph B. Walther characterizes computermediated communication as hyperpersonal, suggesting that, due to lack of visual cues, communicants put more effort into their mediated presentations of self, and are more liable to idealize their communication partners (Walther, 1996; see also Tidwell and Walther, 2002). Mediated communication may be optimal despite, or more precisely due to, the scarcity of visual cues, as participants control the quantity and quality of personal information available to other participants. Lack of a shared physical presence is also appreciated in communication with offline friends, and illustrates how a successful integration of online and offline forms of interaction can benefit established social ties.

Sophia (15, Oslo): I think it's easier to have serious conversations on MSN than anywhere else, because you don't have to look people in the eyes.

Dina (15, Oslo): I think so too. Like, if I'm going to tell somebody about something serious, then I prefer to use, if not MSN [messenger], then at least, to write it. It's much easier. You can emphasize more strongly how to express something than when you talk, because then you really just have to take it then and there.

Similar views are found in all of the interviews. Nina (16, Oslo) argues that "often you don't want to say something to someone, you just bring it up in MSN and then you're done with it." Trine, a 15-year-old, continues "Or to bring up awkward things on MSN or just confessing there. Because then it will be easier to meet this person." These accounts indicate the interdependence between online and offline forms of communication. Similarly, research shows that users present more courageous selves when social interaction is mediated (Henderson and Gilding, 2004; Lüders, 2007; Oksman and Turtiainen, 2004), and as a result, levels of intimacy between friends may increase (Henderson and Gilding, 2004; Hu et al., 2004).

Andreas (18, Ski): It's easier to express oneself accurately online, and hence online conversations are often profound and very open. You can write it down, 
and have a second look at what you're intending to say. If you don't like how you expressed something, you can just edit it. Then it's easier to be honest, and I think it's easier to tell people what I really feel.

Reciprocal confessions of thoughts and feelings are essential for the development of close relationships and friendships (Bargh et al., 2002; Brandtzæg and Stav, 2004; Derlega, 1993; Giddens, 1991; Jamieson, 1998; Laursen, 1996; Mesch and Talmud, 2006), and practices online appear to have consequences for the further development of existing social relationships. With the absence of physical presence in mediated interactions, communicants put more effort into their presentations of self, and self-revelations are consequentially more controlled. Hence, somewhat paradoxically, mediated presentations of selves are both more managed and more open and honest.

Linnea (18, Oslo): I sometimes prefer to have written conversations with particular people. Because when I meet them, well, the mood isn't quite the same as online. It's more about joking and having fun, but we have a special different connection online. Which doesn't really fit face-to-face. We're really good friends, but it's easier to be personal online.

Therefore, although the informants explicitly claim to prefer face-to-face communication, mediated forms of communication assist in the process of developing close relationships by enhancing intimacy and loyalty. Personal media are important arenas for increasing confidence between friends, as some things are more easily confessed in mediated interactions.

If reciprocal self-disclosure increases trust and confidence among friends, it is analytically pertinent to differentiate between types of friendships. People have (or commonly desire to have) romantic partners, intimate friends, friends, contacts and associates. LiveJournal is a particularly good example of a differentiated system that allows users to create several groups of friends according to types of friendships. LiveJournal users have the option to restrict access to their journal or to designate specific entries for defined friends only. When users update their journals, they can choose which groups will have access to read their entries and give their very closest friends access to their most private entries.

Morten (17, Larvik): I've added many people to my LiveJournal friends list to be able to keep track of their updates. Maybe they think they get to read all of my closed entries, but they can't because they are not in the right friends group.

In this way, social technologies make the different characteristics of ties more explicit: friends and contacts are distinguished according to the quality of the specific relationship, or in network-theoretical terms, the strength of the tie. Personal media are important social symbols that indicate social success (Ling, 2004), yet there are significant differences concerning how and with whom different personal media are used (Licoppe and Smoreda, 2005). Motivation to communicate increases with the strength of a social tie, and strongly tied pairs communicate more and use more media to interact (Haythornthwaite, 2002). With maturing social ties, users may change who "deserve" a place in their most intimate friend group. Similarly, there are correlations between types of media used to support different relationships. While the telephone is particularly important for communication between strongly tied pairs, IM, IRC and blogs do not have the same exclusive and intimate characteristics. First of all, there is an obvious difference in the public reach of conversations: IRC chats are most commonly open for all to participate; 
blogs are commonly open for comments from unknown readers; and social profiles, such as MySpace and MSN profiles function as invitations for further contact through, for instance, IM. However, although IM conversations are private, IM precedes the telephone on a scale of intimacy, i.e. the informants find it easier to talk to people they do not know very well in IM rather than on the phone.

Conversation analyst Ian Hutchby provides useful insights into self-repair in talkin-interaction (Hutchby, 2001), which can help explain a very significant difference between oral and written conversations, and thus why different media appear to be used in different social contexts. As previously noted, with mediated written communication, communicants can revise their expressions before making them public. Henrik (18, Narvik) explains:

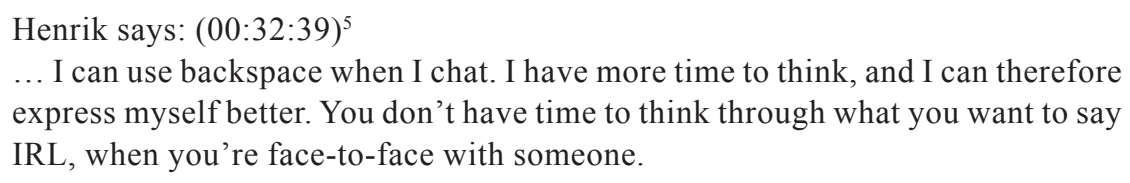

Henrik says: (00:32:58)

I used backspace three times above, and one time on this sentence.

Although, editings of self-expressions are often emphasized as typical of computer-mediated communication, self-repair is equally common in talk. Examples of consecutive efforts to produce sentences "are not necessarily indicators of errors, of getting an utterance wrong, but, among other things, can show speakers designing their utterances so as to be situationally appropriate" (Hutchby, 2001: 74). Whereas processes of self-repair are visible in talk-in-interaction, they can be kept out of sight in written conversations. Hence, temporal discrepancies between telephone conversations and computer-mediated conversations may explain why the telephone is more indicative of close relationships, as intimate friends are more likely to know how to select oral utterances that are situationally appropriate and also less likely to be worried about the visibility of self-repair in talk. These differences in levels of intimacy will be evident in the next part, where the analysis focuses on the role of personal media in initiating new social ties.

To sum up so far, the analysis suggests that the specific qualities of mediated communication may indeed contribute to strengthening social ties by facilitating meaningful and intimate interpersonal interactions between friends. Yet, it is also apparent that the mediated and immediate spheres of social lives are regarded as interconnected. This partially explains the increasing reliance on mediated forms of communication: They are important because they are integrated parts of the informants' lifeworlds.

\section{Extending Social Networks through Online Encounters}

Ulrich Beck and Elisabeth Beck-Gernsheim argue that people in post-traditional societies characteristically have a reflexive relation to their social networks (Beck and Beck-Gernsheim, 2002). A concomitant question can be posed: Are personal media used intentionally to get in touch with certain types of people, such as others similar to oneself? The experiences of the informants are mixed and, at first, deliberate and reflexive intentions of finding friends online do not appear to be the main motivation for online interactions. However, as self-presentations are more controlled and based on self-emphasized personal traits, a composed, yet in many cases relatively accurate, image of the self appears online. The informants' experiences suggest that they identify 
with others when presented personal traits match, and as a result, make the first move to get in touch. Finding similar others can be especially important as adolescence is an important time for self-development, and identification with childhood friends may decrease as friends follow different paths. Changing constellations of friends is natural throughout life, and is often connected to a change in personal social status (Allan, 1989: 61). Similarly, with changing interests and values in adolescent years, personal media can be effective in extending and changing social networks. For instance, Thomas has found friends with interests and values consonant with his own sense of self:

Thomas (17, Nesodden): I wouldn't know the same people without LJ [LiveJournal]. I guess I would've stayed together with my old friends, who I'm not really good friends with anymore. I wouldn't have as many friends as I have now. Would've been forced to keep the friends I once had.

Thomas has never been short of friends, and his reflections concerning the social value of LiveJournal and other means of computer-mediated communication indicate a rather eclectic view of social networking, in the sense that he apparently picks friends according to how interesting he finds them. Morten (17, Larvik) likewise considers it reasonable to choose friends who are similar to himself, and whose company he enjoys. Possibilities of finding similar others is a recognized advantage of computer-mediated communication (McKenna et al., 2002), and Anthony Giddens's concept of "pure relationships" in modern societies presents a useful theoretical context: Modern friendships are pure in the sense that they exist for the purpose of the rewards of the relationship (Giddens, 1991). Relationships that no longer generate sufficient emotional returns can be terminated at will, and according to Thomas and Morten, new similar or interesting others are abundantly available online. Giddens emphasizes that modern urban settings provide ample opportunities for people to search out others with similar interests (Giddens, 1991: 174). With the development of network media, characteristics of modern urban settings seem to extend into online worlds.

A premise for finding similar others online is that users in fact present a more or less accurate image of themselves. Users interacting with offline friends may very well feel less constrained online, yet they still need to conduct themselves in accordance with how friends usually perceive them. However, the informants emphasize that they prefer to "be themselves" also in interaction with online friends. In many cases, they find it easier to communicate, what Bargh et al. terms a "true self", online (Bargh et al., 2002). Linnea (18, Oslo) concomitantly argues that she indeed presents an authentic self, yet a self that is clearly edited:

And you're more anonymous even if your name is there, or even if they know somebody who knows me and they might have read my diary. You can be a little bit different from who you are. And you start with a clean sheet. Presenting your self as you see yourself [emphasis added], ... You can choose what you want to tell.

... it's all me, but it's small parts of me. Maybe it's the parts I'm more satisfied with that I write more about.

To her readers, Linnea seems remarkably honest about her life and her feelings, and she does not present a picture-perfect image of herself or her life. Still she consciously edits the pieces of her self that she wants to share. Understanding why users feel more in control is vital if we are to understand the appeal of online interactions. Whether interaction takes place through IM or diaries, communicants feel less constrained by 
their own physical and facial expressions and reactions: “... when you write something, nobody can see what feelings you have and how you react" (Anders 17, Oslo). Anders's experiences are particularly relevant in this context. He feels quiet and shy with people face-to-face, and finds it easer to open up online. Yet his newfound friends from IRC and LiveJournal are regularly converted into offline friends as he rates face-to-face interactions higher. The integration of online and offline realms is hence vital to his sense of well-being. Kristoffer (18, Oslo), on the other hand, is socially outgoing and, as a case seen as distinct from the other informants, confirms the "rich get richer" hypothesis, indicating that socially outgoing individuals get more social benefit from communication media (Kraut et al., 2002). When compared, Anders's and Kristoffer's experiences prove the complexity of trying to establish definite correlations between certain personality types and the social value of mediated forms of interaction.

Thus far, the discussion has focused on the importance of integrating online and offline social spheres. This is, however, not always possible. The experiences of Kristian and Andreas illustrate how geographical location still is a central aspect of social life, with significant consequences for opportunities to integrate online and offline practices. Kristian comes from a small town on the western coast of Norway, and Andreas lives outside Oslo. Potentials for social interaction are not as good as they would like. Hence the Internet has proved helpful: Kristian (18) says: (16:12:24)
I don't have a lot of friends where I live, and I don't think I want to be friends
with those who live here either... This is a dull little place (which is something
all of us who live here say). Haugesund is a more happening place.

$\cdots$

Kristian says: (17:19:54)

Seriously, there's NOTHING to do here.

Andreas (18): As I've already said, I use IRC and stuff to compensate for the lack of social interaction where I live.

M: How many people do you think you've got to know the last couple of years because of the Internet?

Andreas: I have no idea really. Unbelievably many. A lot of people. When I think about it, I've got to know a lot of people. It feels, like, great.

Andreas lives close to Oslo, and, with online friends living in or near Oslo, opportunities to meet face-to-face have been ample. His online acquaintances have frequently become offline friends. The situation for Kristian is different. Due to lack of friends in his hometown, Kristian previously spent a great deal of time online, chatting in IRC channels. When he started upper secondary school in Haugesund, he met people he identified with and soon preferred to be with his new friends rather than online with IRC contacts, indicating that online relationships maintained only through one channel can be ephemeral. The people he knows from IRC live far away, and it has therefore been difficult to arrange face-to-face meetings. Geographical locations hence have great consequences for potentials to integrate online and offline spaces, and in Kristian's case, they remain relatively independent.

The independence between online and offline spaces can, on the other hand, also be experienced as appealing: It is important to understand the allure and perceived safety 
of getting in touch with strangers because they are strangers. The un-connectedness between oneself and the other is perceived as an asset:

Henrik [18, Narvik] says: (01:03:15)

Maybe I'm more open in [IRC] channels where I don't know people IRL.

M says: (01:03:27)

Because?

Henrik says: (01:03:46)

Because they don't know me irl, and I don't have to meet them face-to-face.

Henrik says: (01:03:55)

which somehow feels safe.

Dina (15, Oslo): I've added people to my friends list on ED [Enjoy Diary], although I only know them from ED. It doesn't really matter, because they know me only from ED. People I know offline can confront me with stuff they've read, or they can tell others. However, if they live in the north of Norway, then it's not very interesting to talk about someone in Oslo to someone who doesn't know who I am.

Dina has some entries open for users who are not on her friends list, and admits to being more private in her restricted posts. Still, her friends list is not exclusive to offline friends, and strangers may be regarded as safe receivers of confessions. Confiding in strangers is not a phenomenon unique to online interactions (Bargh et al., 2002). Strangers may be perceived as safe receivers of intimate self-disclosures, as there appear to be no real-life consequences. Regarding online spaces, McKenna et al. suggest that the relative anonymity experienced in online interactions reduces the risks of intimate disclosures, "because one can share one's inner beliefs and emotional reactions with much less fear of disapproval and sanction" (McKenna et al., 2002: 10).

Online strangers are not regarded as "real" friends, yet, for the informants, mediated interactions, characterized by perceptions of safety and the specific qualities of mediated communication, have regularly resulted in initially weak ties developing into strong ties. Mark Granovetter's definition of the strength of a tie as a "combination of the amount of time, the emotional intensity, the intimacy (mutual confiding), and the reciprocal services which characterize the tie" (Granovetter, 1973: 1361) can be applied to demonstrate how online relationships may develop from weaker to stronger. Marte (15, Trondheim) describes what it can be like:

M says: (16:31:27)

Would you say that you've got to know people well online?

Marte says: $(16: 31: 57)$

hmm. yes, actually. have some people that i've actually never meet in reality who i 'know' pretty well.

M says: $(16: 32: 22)$

how do you know them? do you talk about anything?

Marte says: (16:32:41)

yes, like any conversation that i could have in reality. 
Marte has a solid companionship with several of her online friends, and some of these ties can be characterized as strong. Incrementally the emotional intensity between online associates increases, trust develops and casual acquaintances become real friends. Weak ties may hence grow strong even when users have never met face-to-face. However, several informants emphasize that interpersonal communicative practices need to be of a certain private quality in order to qualify as characterizing interaction between friends:

M says: (13:49:46)

do you think you know people that you've only talked to online?

M says: (13:50:59)

or like through comments on myspace?

Jon [19, Stavanger] says: (13:52:59)

You get an impression of people. But it takes more time, even if you do sense if someone is nice or not. But I wouldn't say that I know somebody just because they've posted a couple of comments to me on myspace. However if it is taken further to like msn [instant messenger], mobile or a face-to-face meeting, then it's more real.

Like most of the other informants, Jon differentiates between forms of mediated communication and perceives face-to-face communication to be of a special character. Strong feelings may develop between online acquaintances, and the strength of the tie is reflected in the usage of communication media. Romances are especially interesting, as they imply that romantic feelings are sometimes initiated through mediated interactions. Dina's (15, Oslo) relationship to her boyfriend advanced from reciprocal reading and commenting in online diaries, to more exclusive and private means of communication such as IM and telephone conversations. Their relationship grew stronger with increasing contact, and they identified themselves as boyfriend and girlfriend after seven months of correspondence. Another seven months of intense mediated interaction went by before they finally met face-to-face. Although profound emotions had already developed, the "realness" of the first face-to-face meeting boosted their relationship to the next level.

This insistent preference for face-to-face interaction emphasizes the special atmosphere between individuals who share a spatial and temporal presence. Erving Goffman's work on context-dependent face-to-face performances (Goffman, [1959] 1990) may partially explain why face-to-face meetings are persistently prioritized as more authentic, and has been revised to fit both electronically mass mediated forms of interaction (Meyrowitz, 1986) and mediated forms of interpersonal interaction (Ellison et al., 2006; Kendall, 2002; Markham, 1998; Papacharissi, 2002; Sveningsson, 2001). According to Goffman, we take on specific characters to please our current audience. In everyday social situations, we are deliberately conscious of matching our presentations of self to expectations of the roles we embody. Yet in face-to-face performances, we cannot control all of the expressions given off (e.g. drifting eyes, blushing cheeks or other presumably unintentional cues). Possibilities for impression management are better (although far from total) in mediated interactions. The relative shortage of involuntary expressions given off in online encounters means communicators are unlikely to fully trust someone they have not met face-to-face (Kendall, 2002: 157), and face-to-face meetings are hence a logical next step when social ties between communicants have grown stronger. In interactions with distant others, the mind fills in the missing visual and expressive parts, but in the end communicants become anxious to compare their constructed impressions of the other 
with the immediate representation. Phenomenologically, we experience the world "in terms of differing degrees of closeness and remoteness, both spatially and temporally" (Berger and Luckmann, 1967: 22). Edward T. Hall's work on proxemics sheds further light on the significance of spatial closeness and remoteness (Hall, [1966] 1969). Hall distinguishes between four spatial zones characterized by different ranges of interpersonal distance: the intimate, the personal, the social and the public. The distances of the zones are culturally dependent, but the pattern is the same: The voluntarily selected gap between people indicates the closeness of the relationship. Consequently, space can be said to be an essential aspect of personal relationships. In-person meetings are therefore experienced differently from mediated meetings, because there is little sense of spatial intimacy or remoteness in mediated interactions.

To sum up, it appears that when the informants meet strangers online, comfort derives from the perceived independence between online and offline spheres. In the process of getting to know significant others online, an urge to connect the two spheres appears to develop, turning online and offline arenas into interdependent spheres. As the analysis has demonstrated, with reciprocal self-disclosure initial strangers become friends and weak ties grow strong. Mediated communication encourages the desire to meet face-to-face and, although several informants perceive their online contacts as "real friends", taking relationships from mediated to immediate arenas serves as a proof of authenticity.

\section{Conclusion and Implications for Future Research}

Personal media are pragmatically and un-dramatically incorporated into the everyday lives of the informants. The specific qualities of mediated communication appear to encourage reciprocal self-disclosure, but this is not an automatic or un-reflexive action. Mediated self-disclosure strengthens already strong offline ties, and initial strangers sometimes become close friends through repeated mediated meetings and incremental increases in mutual confidence. Throughout the analysis, I emphasize the importance of integrating online and offline interactions in everyday life in meaningful ways, and I suggest that the ability to do so might be an important indicator of social well-being. For the informants, mediated spheres of interaction represent important social contexts, and skilled social behaviour (indicating social competence) includes the ability to make the most of mediated as well as immediate social spaces. This appears to be the case for shy as well as for extrovert informants, suggesting that a life consisting merely of mediated meetings is considered to be unappealing. The urge to bring meaningful online relationships to offline realms is evident, and face-to-face contact is still the preferred mode of interaction. It is nonetheless interesting to explore how the insistent preference for face-to-face interaction among users (as seen in the present study) is actually mirrored in time spent with friends face-to-face. Complex and extensive social networks may necessitate that social ties be maintained partly, or in many cases, mainly through mediated interaction. Yet the fact that face-to-face interaction is emphasized to such a degree as "better" and more "authentic" by users suggests that there may still be social stigmas connected to the exaggerated use of computer-mediated communication (e.g. owing to insufficient skills in integrating online and offline forms of interaction).

Importantly, the above analysis suggests that the qualities of mediated communication differ from face-to-face communication, not by being less meaningful, but by enabling other forms of disclosing practices. The informants' mediated interpersonal 
performances greatly influence the character of their social ties and networks. Because mediated and immediate arenas are intertwined, the social implications appear to be highly significant and "real". Consequently, it is tempting to question whether individuals, especially adolescents, who do not take part in mediated interactions (who for example regard mediated forms of communication to be of a lesser quality) miss out on meaningful social practices. It may seem to be important to explore the possible stigmas attached to young people who, for some reason, do not take part in mediated social arenas. Clearly, given that the present study does not include adolescents who choose to refrain from mediated spaces, this is presented merely as a provocative reflection, suggesting a potentially important area for future research.

\section{Notes}

1. MSN Messenger is currently called Windows Live Messenger.

2. Information about the hometowns of the informants is included throughout the article. A brief description is provided here, as these places may be unknown to the reader: Narvik is situated in northern Norway (population 18,512); Trondheim is situated in central Norway (population 156,161); Stavanger is situated on the western coast of Norway (population 155,157); Nesodden and Ski are municipalities close to Oslo (population 16,231 and 26,800); and Larvik is situated on the south-eastern coast of Norway (population 41,142 ). In addition, one informant comes from a small town on the western coast of Norway (population about 2000). Population statistics from Statistics Norway (http://www.ssb.no).

3. http://tamsys.sourceforge.net/

4. Use of social network services among the informants has changed since the interviews. For example, 13 informants have now (as of 13 June 2007) registered as users on Facebook, 5 with public profiles and 8 with private profiles.

5. Interview extracts with time-stamps indicate that the interview has been conducted using IM.

\section{References}

Allan, G. (1989) Friendship: Developing a Sociological Perspective. New York: Harvester Wheatsheaf.

Barabási, A.-L. (2003) Linked: How Everything is Connected to Everything else and what it Means for Business, Science, and Everyday Life. New York: Plume.

Bargh, J.A., McKenna, K.Y.A., \& Fitzsimons, G.M. (2002) 'Can You See the Real Me? Activation and Expression of the "True Self" on the Internet', Journal of Social Issues, 58(1): 33-48.

Barney, D. (2004) 'The Vanishing Table, or Community in a World that is no World', in Barney, D., \& Feenberg, A. (eds.) Community in the Digital Age: Philosophy and Practice, pp. 31-52. Lanham, Md.: Rowman \& Littlefield.

Baym, N., \& Zhang, Y.B. (2004) 'Social Interactions Across Media. Interpersonal Communication on the Internet, Telephone and Face-to-Face', New Media and Society, 6(3): 299-318.

Beck, U., \& Beck-Gernsheim, E. (2002) Individualization: Institutionalized Individualism and Its Social and Political Consequences. London: Sage.

Berger, P.L., \& Luckmann, T. (1967) The Social Construction of Reality: A Treatise in the Sociology of Knowledge. Garden City, N.Y.: Doubleday.

Blumer, H. ([1969] 1998) Symbolic Interactionism: Perspective and Method. Los Angeles: University of California Press.

Boase, J., Horrigan, J.B., Wellman, B., \& Rainie, L. (2006) The Strength of Internet Ties. Washington: Pew Internet \& American Life Project.

Brandtzæg, P.B., \& Heim, J. (2007) 'Survey of online Communities', in Brandtzæg, P.B. (Ed.) Initial Context, User and Social Requirements for the CITIZEN MEDIA Applications: Usage and Motivations in off- and online Communities, pp. 13-40.

Brandtzæg, P.B., \& Stav, B.H. (2004) 'Barn og unges skravling på nettet. Sosial støtte i cyberspace?' ['Online chatting among children and youth. Social support in cyberspace?'], Tidsskrift for Ungdomsforskning [Journal of Youth Research], 4 (1): 27-47.

Cavell, T.A. (1990) 'Social Adjustment, Social Performance, and Social Skills: A Tri-Component Model of Social Competence', Journal of Clinical Child Psychology, 1(2): 111-122.

Derlega, V.J. (1993) Self-disclosure. Newbury Park, Cal.: Sage. 
Donath, J., \& Boyd, D. (2004) 'Public Displays of Connection', BT Technology Journal, 22(4): 71-82.

Ellison, N., Heino, R., \& Gibbs, J. (2006) 'Managing Impressions Online: Self-Presentation Processes in the Online Dating Environment', Journal of Computer-Mediated Communication, 11(2).

Fortunati, L. (2005) 'Is Body-to-Body Communication Still the Prototype?', The Information Society, 21(1): 53-61.

Gergen, K.J. (2002) 'The Challenge of the Absent Presence', in Katz, J.E., \& Aakhus, M.A. (Eds.) Perpetual Contact: Mobile Communication, Private Talk, Public Performance, pp. 227-241. Cambridge: Cambridge University Press.

Giddens, A. (1991) Modernity and Self-Identity: Self and Society in the Late Modern Age. Cambridge: Polity Press.

Goffman, E. ([1959] 1990) The Presentation of Self in Everyday Life. London: The Penguin Press.

Granovetter, M.S. (1973) 'The Strength of Weak Ties', The American Journal of Sociology, 78(6): 1360-1380.

Hall, E.T. ([1966] 1969) The Hidden Dimension: Man's Use of Space in Public and Private. London: The Bodley Head.

Haythornthwaite, C.A. (2002) 'Strong, Weak, and Latent Ties and the Impact of New Media', The Information Society: an International Journal, 18(5): 385-401.

Hegna, K. (2005) “Likestillingsprosjektets” barn: endringer i kjønnsforskjeller blant ungdom fra 1992 til 2002 [The children of the gender equality project: transforming gender differences among youth between 1992 and 2002]. Oslo: Nova.

Heim, J., Brandtzæg, P.B., Hertzberg Kaare, B., Endestad, T., \& Torgeresen, L. (2007) 'Children's Usage of Media Technologies and Psychosocial Factors', New Media \& Society, 9(3): 425-454.

Henderson, S., \& Gilding, M. (2004) 'I've Never Clicked This Much with Anyone in My Life": Trust and Hyperpersonal Communication in Online Friendships', New Media and Society, 6(4): 487-506.

Herring, S.C. (2004) 'Slouching Toward the Ordinary: Current Trends in Computer-Mediated Communication', New Media and Society, 6(1): 26-36.

Hu, Y., Fowler Wood, J., Smith, V., \& Westbrook, N. (2004) 'Friendships through IM: Examining the Relationship between Instant Messaging and Intimacy', Journal of Computer-Mediated Communication, 10(1).

Hutchby, I. (2001) Conversation and Technology: From the Telephone to the Internet. Cambridge: Polity Press.

Jamieson, L. (1998) Intimacy: Personal Relationships in Modern Societies. Cambridge: Polity Press.

Kendall, L. (2002) Hanging Out in the Virtual Pub: Masculinities and Relationships Online. Berkeley, Calif.: University of California Press.

Kraut, R., Kiesler, S., Boneva, B., Cummings, J., Helgeson, V., \& Crawford, A. (2002) 'Internet Paradox Revisited', Journal of Social Issues, 58 (1): 49-74.

Laursen, B. (1996) 'Closeness and Conflict in Adolescent Peer Relationships: Interdependence with Friends and Romantic Partners', in Newcomb, A.F., Hartup, W.W., \& Bukowski, W.M. (Eds.) The Company they Keep: Friendships in Childhood and Adolescence, pp. 186-210. Cambridge: Cambridge University Press.

Lenhart, A., Madden, M., \& Hitlin, P. (2005) 'Teens and Technology. Youth are Leading the Transition to a Fully Wired and Mobile Nation’, Pew Internet \& American Life Project, URL (consulted: 12 September 2006): http://www.pewinternet.org/report_display.asp? $\mathrm{r}=162$

Licoppe, C., \& Smoreda, Z. (2005) 'Are Social Networks Technologically Embedded? How Networks are Changing Today with Changes in Communication Technology', Social Networks, 27(4): 317-335.

Ling, R. (2004) The Mobile Connection: The Cell Phone's Impact on Society. Amsterdam: Elsevier.

Livingstone, S., \& Bober, M. (2004) UK Children Go Online. Surveying the Experiences from Young People and their Parents. London: Economic and Social Research Council.

Livingstone, S., \& Bober, M. (2005) UK Children Go Online. Final Report of Key Project Findings. London: Economic and Social Research Council.

Lüders, Marika (2007) 'Private subjekter i digitale miljøer: iscenesettelse i endring?' [Mediated subjects: how personal media affect performances of selves], in Lüders, M., Prøitz, L., \& Rasmussen, T. (Eds.) Personlige medier: Livet mellom skjermene, pp. 226-246. Oslo: Gyldendal Akademisk

Markham, A. N. (1998) Life Online: Researching Real Experience in Virtual Space. Walnut Creek, Calif.: Altamira Press.

McCall, G.J. (2003) 'Interaction', in Reynolds, L.T., \& Herman-Kinney, N.J. (Eds.) Handbook of Symbolic Interactionism, pp. 327-348. Walnut Creek, Calif.: AltaMira Press.

McKenna, K.Y.A., Green, A.S., \& Gleason, M.E.J. (2002) 'Relationship Formation on the Internet: What's the Big Attraction’, Journal of Social Issues, 58 (1): 9-31.

Mesch, G., \& Talmud, I. (2006) 'Online Friendship Formation, Communication Channels, and Social Closeness’, International Journal of Internet Science, 1(1): 29-44.

Meyrowitz, J. (1986) No Sense of Place: The Impact of Electronic Media on Social Behavior. New York, N.Y.: Oxford University Press. 
Oksman, V., \& Turtiainen, J. (2004) 'Mobile Communication as a Social State: Meanings of Mobile Communication in Everyday Life among Teenagers in Finland', New Media and Society, 6(3): 319-339.

Papacharissi, Z. (2002) 'The Presentation of Self in Virtual Life: Characteristics of Personal Home Pages', Journalism \& Mass Communication Quarterly: Published by the Association for Education in Journalism and Mass Communication, 79(3): 643-660.

Poster, M. (2001) What's the Matter with the Internet? Minneapolis: University of Minnesota Press.

Rasmussen, T. (2007) 'Nettverksintegrasjon og personlige medier' [Network integration and personal media], in Lüders, M., Prøitz, L., \& Rasmussen, T. (Eds.) Personlige medier: livet mellom skjermene [Personal media: life between screens], pp. 247-269. Oslo: Gyldendal.

Statistics Norway (2005) 'Norsk mediebarometer 2004' [Norwegian media barometer 2004], Statistics Norway, URL (consulted: 12 January 2007): http://www.ssb.no/emner/07/02/30/medie/

Sveningsson, M. (2001) Creating a Sense of Community: Experiences from a Swedish Web Chat. Linköping: Tema, Univ.

Tidwell, L.C., \& Walther, J.B. (2002) 'Computer-Mediated Communication Effects on Disclosure, Impressions, and Interpersonal Evaluations’, Human Communication Research, 28(3): 317-348.

Torgersen, L. (2004) Ungdoms digitale hverdag: bruk av PC, Internett, TV-spill og mobiltelefon blant elever på ungdomsskolen og videregående skole [The digital everyday life of youths: use of PC, the Internet, computer-games and mobile phones among pupils in secondary school and high school]. Oslo: Nova.

Tönnies, F., \& Loomis, C.P. (1955) Community and Association. London: Routledge and Kegan Paul.

Walther, J.B. (1996) 'Computer-Mediated Communication: Impersonal, Interpersonal, and Hyperpersonal Interaction', Communication Research, 23(1): 3-43.

Wellman, B. (2001) 'The Persistence and Transformation of Community: From Neighbourhood Groups to Social Networks', The Law Commission of Canada.

Wellman, B. (2002) 'Little Boxes, Glocalization, and Networked Individualism', in Tanabe, M., van den Besselaar, P., \& Ishida, T. (Eds.) Digital Cities II: Computational and Sociological Approaches, pp. 10-25. Berlin: Springer.

Wellman, B., \& Haythornthwaite, C.A. (2002) The Internet in Everyday Life. Oxford: Blackwell.

Yin, R.K. (1994) Case Study Research: Design and Methods. Thousand Oaks, Calif: Sage.

MARIKA LÜDERS, Ph.D., Researcher, SINTEF ICT, Cooperatuive and Trusted Systems, Oslo,marika.luders@sintef.no 